\section{Statistical Significance}

A Stretched Currents
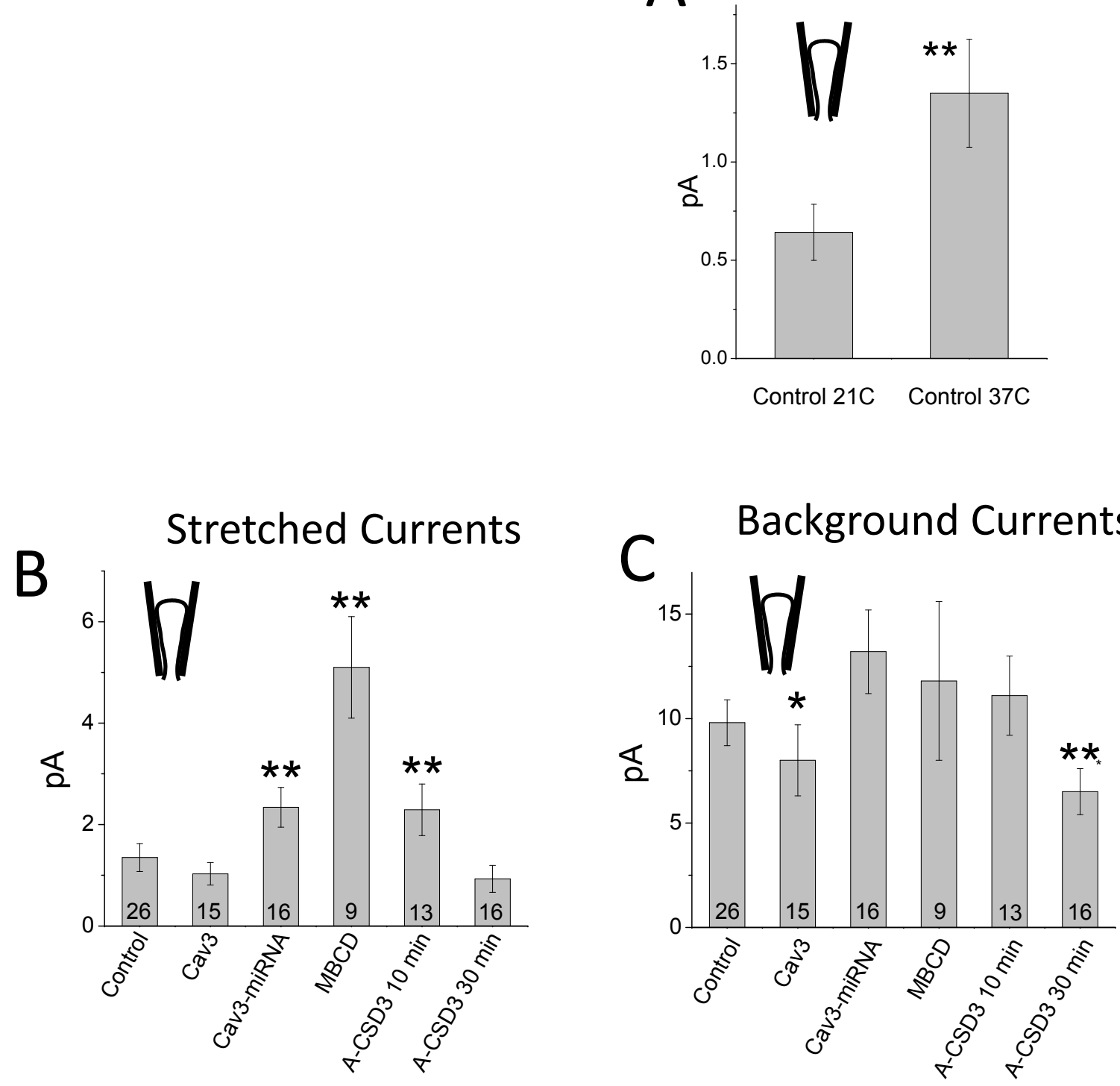

Supporting

Figure S6

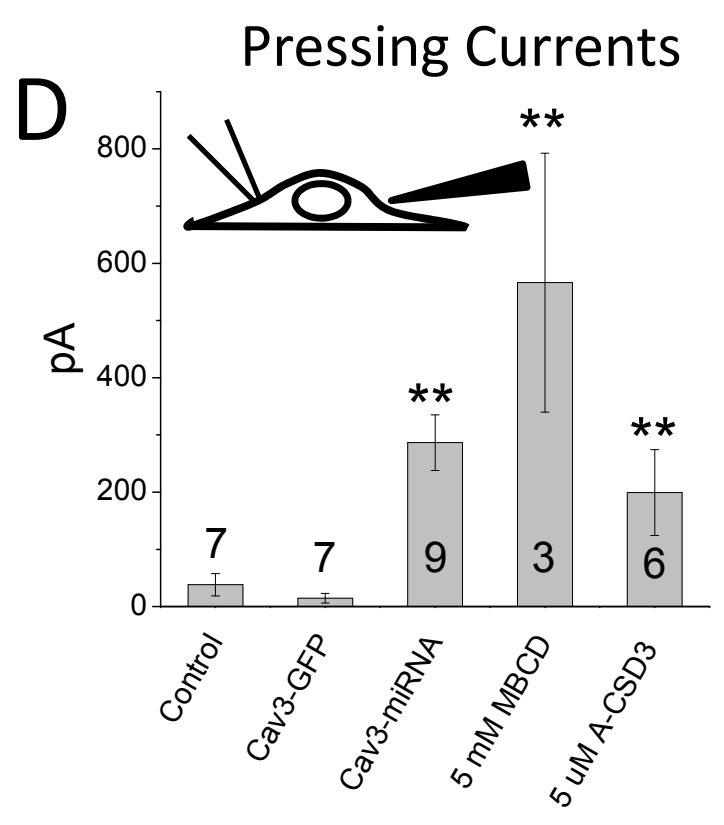

